\section{REFLEKSI HUKUM}

Jurnal Ilmu Hukum
p-ISSN 2541-4984 | e-ISSN 2541-5417

Volume 3 Nomor 2, April, Halaman 175-192

DOI: https://doi.org/10.24246/jrh.2019.v3.i2.p175-192

Open access at: http:// ejournal.uksw.edu/refleksihukum

Penerbit: Fakultas Hukum Universitas Kristen Satya Wacana

\title{
KAJIAN YURIDIS KLAUSULA ARBITRASE DALAM PERKARA KEPAILITAN
}

\author{
Marihot Janpieter Hutajulu \\ Fakultas Hukum Universitas Kristen Satya Wacana \\ Korespondensi: marihotjanpieter@gmail.com
}

\begin{abstract}
Abstrak
Penyelesaian sengketa melalui arbitrase sudah menjadi sarana penyelesaian sengketa utangpiutang yang berlaku universal di dunia perniagaan. Namun, ketika terjadi sengketa di antara kreditor dan debitor, klausula arbitrase yang telah disepakati di dalam perjanjian utang-piutangnya dimungkinkan untuk disimpangi dengan mengajukan permohonan kepailitan kepada pengadilan niaga. Tulisan ini hendak mendiskusikan bagaimana klausula arbitrase dalam perkara kepailitan dikaitkan dengan prinsip Commercial Exit from Finansial Distress dalam hukum kepailitan yang seharusnya diutamakan dalam setiap penyelesaian perkara kepailitan. Penelitian ini menemukan adanya ketidakharmonisan antara UU Arbitrase dan UU Kepailitan di Indonesia dalam konteks pengutamaan prinsip penyelesaian sengketa bisnis melalui arbitrase dan prinsip lembaga kepailitan sebagai sarana untuk menolong debitor yang beritikad baik. Namun demikian, putusan pengadilan niaga masih ada yang konsisten menyatakan tidak berwenang untuk memeriksa dan mengadili permohonan kepailitan yang di dalam perjanjian bisnis di antara kreditor dan debitornya telah berisi klausula arbitrase.
\end{abstract}

Kata Kunci : Penyelesaian Sengketa; Arbitrase; Kepailitan; Pengadilan Niaga.

\begin{abstract}
Arbitration is universally known as a tool of out-of-court settlement to solve debt dispute between a creditor and a debtor in a commercial activity. In fact, arbitration clauses which are agreed by the parties of a business contract might be deviated by submitting the bankruptcy dispute before the commercial court. This study discusses the relationship between arbitration clause in bankruptcy dispute and the principle of 'commercial exit from finansial distress' in bankruptcy law which has to be prioritized in each bankruptcy dispute. In conclusion, the study discovers a disharmony between Arbitration Law and Bankruptcy Law in Indonesia in the context to stress arbitration as an instrument of dispute resolution and the principle of bankruptcy institution as a mean to assist the debtor who already has good faith to pay his debts. However in practice, there are some decisions of commercial courts that states consistently they have no authority to examine and adjudicate bankruptcy dispute on the business contract between creditor and debitor.
\end{abstract}

Keywords: Dispute Resolution; Arbitration; Bankruptcy; Commercial Court. 


\section{PENDAHULUAN}

Dunia perniagaan pada umumnya sangat mengedepankan pentingnya saling percaya (trust) di antara para pelakunya. Sebelum para pelaku bisnis mengadakan hubungan perniagaan, konsensus dilakukan melalui proses negosiasi yang tidak sekali jadi. Para pihak saling menawarkan dan meminta syarat-syarat tertentu yang akan menjadi hak dan kewajiban para pihak nantinya. Dengan adanya kesepakatan mengenai syarat-syarat tersebut, timbul saling percaya yang memungkinkan para pihak untuk melanjutkan kerja sama bisnis.

Walaupun ada saling percaya di antara pelaku bisnis, peranan kontrak juga penting untuk memberikan rasa aman dan kepastian hukum dalam melakukan transaksi bisnis. Perjanjian atau kontrak bisnis lazimnya dituangkan dalam bentuk surat atau akta, yang berbentuk akta di bawah tangan atau akta autentik. Kontrak tersebut disusun sedemikian rupa mencakup hal-hal yang mengatur hubungan hukum para pihak, yang hubungan tersebut dapat saja di kemudian hari tidak berjalan sesuai perjanjiannya. Untuk mengantisipasi masalah, di dalam kontrak juga dimasukkan ketentuan-ketentuan yang akan menjadi acuan dalam menyelesaikan sengketa yang di kemudian hari.

Salah satu ketentuan penting di dalam perjanjian atau kontrak bisnis adalah ketentuan atau klausula tentang penyelesaian sengketa, yang mengatur masalah forum dan hukum apa yang akan diberlakukan terhadap sengketa yang timbul. Pelaku bisnis cenderung menghindari penyelesaian sengketa melalui pengadilan, dan memilih untuk menyelesaikannya melalui lembaga di luar pengadilan.

Arbitrase adalah salah satu lembaga penyelesaian sengketa di luar pengadilan. Di dalam kontrak bisnisnya, para pihak memasukkan klausula tentang lembaga arbitrase yang dipilih sebagai forum untuk menyelesaikan sengketa mereka. Nama lembaga arbitrase yang akan menyelesaikan sengketa serta hukum mana yang akan dipakai di dalam forum arbitrase tersebut dinyatakan secara tegas di dalam kontrak bisnisnya. Adanya asas kebebasan berkontrak turut mendukung para pihak untuk memasukkan klausula arbitrase tersebut, yang jika dibandingkan dengan lembaga pengadilan, lembaga arbitrase mempunyai kelebihan berupa kebebasan, pilihan, otonomi, dan kerahasiaan kepada para pihak yang bersengketa. ${ }^{1}$

Dalam praktik bisnis, ada banyak perjanjian yang dapat diadakan oleh para pelakunya, antara lain perjanjian utang-piutang yang dibuat antara kreditor dan debitor. Perjanjian utangpiutang tersebut tidak selalu dilaksanakan sesuai kesepakatan para pihak. Ada kalanya debitor mengalami kegagalan (wanprestasi) dalam memenuhi kewajibannya, yang berujung kepada timbulnya sengketa. Sengketa utang-piutang tersebut dapat dibawa oleh kreditor ke pengadilan dengan melakukan gugatan perdata, bahkan sampai kepada pengajuan permohonan kepailitan terhadap debitornya.

Kreditor yang memiliki perjanjian utang-piutang dengan debitor yang diajukan permohonan pailit, di dalam

Agnes M. Toar (et.al), Arbitrase di Indonesia, Seri Dasar-Dasar Hukum Ekonomi 2 (Ghalia Indonesia 1995) 7. 
perjanjian utang-piutang tersebut ada yang telah mencantumkan klausula arbitrase. Klausula arbitrase dapat dimasukkan sepanjang perjanjian utang-piutang tersebut tidak bertentangan dengan undang-undang (UU), moral, ketertiban umum, kepatutan dan kebiasaan sebagaimana dimaksud oleh ketentuan Pasal 1337 dan Pasal 1339 Kitab Undang-Undang Hukum Perdata (KUHPer). ${ }^{2}$ Karena setiap perjanjian atau kontrak bisnis (perjanjian utang-piutang) yang dibuat secara sah mengikat sebagai UU, maka pada saat terjadi sengketa, adanya klausula arbitrase mengharuskan para pihak untuk membawa sengketa tersebut kepada lembaga arbitrase.

Persoalan muncul ketika salah satu pihak tidak membawa sengketa utang-piutang tersebut untuk diselesaikan melalui pengadilan perdata biasa, melainkan langsung mengajukan permohonan untuk memailitkan si debitor ke pengadilan niaga. Kepailitan menyebabkan semua harta benda debitor disita secara umum. Sengketa kepailitan pada dasarnya timbul dari perjanjian utang-piutang. Sengketa kepailitan dipilih oleh para pihak sebagai upaya untuk meletakkan harta debitor di bawah sita umum. Dengan diletakkan di bawah sita umum, maka debitor tidak berwenang lagi mengurus hartanya, melainkan harta debitor tersebut dikuasai dan diurus oleh kurator yang ditetapkan oleh pengadilan.

Proses kepailitan sebenarnya dimaksudkan untuk melindungi kepentingan kreditor dan debitor secara berimbang. Hukum kepailitan itu haruslah dapat memberikan perlindungan hukum kepada masyarakat, kreditor, dan debitor secara adil. ${ }^{3}$ Proses kepailitan yang berlangsung di pengadilan niaga tidak boleh dimaksudkan semata-mata untuk mengakhiri bisnis atau usaha dari seorang debitor, melainkan juga bertujuan untuk memberikan kesempatan bagi para pihak yang berkepentingan untuk menyelesaikan sengketa utangpiutang secara berkepastian dan berkeadilan. Dalam literatur hukum kepailitan dikenal prinsip Commercial Exit from Financial Distress. ${ }^{4}$ Dengan adanya prinsip ini, maka hukum kepailitan sebenarnya hendak memberikan keseimbangan kedudukan di antara kreditor dan debitor, terutama debitor yang beritikad baik.

Dalam UU No. 37 Tahun 2004 tentang Kepailitan (selanjutnya disebut UU Kepailitan) ternyata ada ketentuan hukum yang dapat meniadakan prinsip hukum penyelesaian sengketa melalui lembaga arbitrase. Pasal 303 UU ini menyebutkan: "Pengadilan tetap berwenang memeriksa dan menyelesaikan permohonan pernyataan pailit dari pihak yang terikat perjanjian yang memuat klausula arbitrase, sepanjang utang yang menjadi dasar permohonan pernyataan pailit telah memenuhi ketentuan sebagaimana dimaksud dalam Pasal 2 ayat (1) Undang-Undang ini." Ketentuan tersebut terkesan sangat "generalis" dan tidak merinci lebih jauh jenis perjanjian utang-

\footnotetext{
Sutan Remy Sjahdeini, Kebebasan Berkontrak dan Perlindungan Yang Seimbang Bagi Para Pihak Dalam Perjanjian Kredit Bank di Indonesia (PT Pustaka Utama Grafiti 2009) 133.

Syamsudin M. Sinaga, Hukum Kepailitan Indonesia (Tatanusa 2012) 44.

M. Hadi Subhan, Hukum Kepailitan. Prinsip, Norma, dan Praktik di Peradilan (Kencana Prenada Media Group 2008) 189.
} 
piutang yang mana yang dimaksudkan, termasuk jika para pihaknya ada unsur subyek hukum asing dan hukum asing yang diberlakukan terhadap perjanjian utang-piutang tersebut. Di dalam penjelasan Pasal 303 UU Kepailitan tersebut dinyatakan: "Ketentuan dalam Pasal ini dimaksudkan untuk memberi penegasan bahwa Pengadilan tetap berwenang memeriksa dan menyelesaikan permohonan pernyataan pailit dari para pihak, sekalipun perjanjian utang-piutang mereka buat memuat klausula arbitrase".

Klausula arbitrase pada hakikatnya bertujuan untuk menghindari lembaga pengadilan sebagai lembaga penyelesaian sengketa yang timbul dari kontrak. Pertimbangan utama para pihak untuk memilih arbitrase, dan tidak memilih lembaga peradilan dalam menyelesaikan sengketa, pada umumnya dikaitkan dengan faktor waktu dan biaya. Lembaga arbitrase juga memiliki anggota yang terdiri dari berbagai keahlian, seperti ahli dalam perdagangan, industri, perbankan, dan hukum. ${ }^{5}$ Dengan mencantumkan klausula arbitrase, para pihak akan lebih diuntungkan karena mereka dapat memilih jenis-jenis sengketa yang dapat diselesaikan secara arbitrase, metode dalam memilih arbiter, prosedur arbitrase, aturanaturan arbitrase yang harus diikuti, tempat arbitrase, dan hukum substantif yang berlaku bagi sengketa ${ }^{6}$, sesuatu hal yang tidak mungkin terjadi pada lembaga peradilan umum.

Pengadilan niaga memiliki kewenangan untuk memeriksa dan mengadili perkara kepailitan, di samping perkara lain di bidang perniagaan. ${ }^{7}$ Dalam praktik, masalah kepailitan yang berkaitan dengan perjanjian utang piutang yang di dalamnya diatur klausula arbitrase telah menimbulkan persoalan, yang debitornya menyatakan bahwa pengadilan niaga tidak berwenang mengadili perkara karena sesuai dengan akta perjanjian, yang masalah tersebut dimunculkan dalam Perkara No. 18/Pailit/2004/PN.NiagaJkt.Pst. 8 Melalui penelitian ini, penulis tertarik untuk menganalisis persoalan klausula arbitrase yang terdapat dalam perjanjian utang-piutang, yang terkait dengan adanya permohonan pailit terhadap debitor dari perjanjian utang-piutang tersebut, yang permohonan pailit tersebut diajukan oleh kreditornya.

Berdasarkan uraian di atas, penelitian ini akan mengangkat 3 (tiga) permasalahan. Pertama, apakah klausula arbitrase dapat menghentikan proses pengajuan permohonan kepailitan terhadap debitor? Kedua, apakah kewenangan pengadilan niaga untuk mengenyampingkan klausula arbitrase bertentangan dengan prinsip Commercial Exit from Financial Distress? Ketiga, bagaimana hakim pengadilan niaga dalam mempertimbangkan klausula arbitrase dalam perjanjian utang-piutang kreditor dan debitor yang diajukan pailit oleh kreditornya? 


\section{PEMBAHASAN}

\section{Konsep Kepailitan sebagai Salah Satu Sarana Penyelesaian Sengketa Utang-Piutang}

Dalam ilmu hukum, hukum penyelesaian sengketa merupakan hukum yang penting bagi masyarakat. Di dalam setiap masyarakat dapat dijumpai bermacam-macam cara untuk memperoleh kesepakatan dalam proses perkara atau untuk menyelesaikan sengketa, yang dalam perkembangannya, masyarakat mulai beralih dari cara-cara sesuai kebiasaan kepada cara-cara hukum. ${ }^{9}$ Secara teoretik, hukum penyelesaian sengketa dibedakan menjadi hukum penyelesaian sengketa secara litigasi dan non litigasi. Penyelesaian sengketa secara litigasi dilakukan di hadapan badan peradilan umum, sedangkan penyelesaian sengketa secara non litigasi berlangsung di luar pengadilan. Litigasi merupakan suatu proses gugatan, suatu konflik yang diritualisasikan yang menggantikan konflik sesungguhnya, yaitu para pihak dengan memberikan kepada seorang pengambil keputusan dua pilihan yang bertentangan. ${ }^{10}$

Sutton et.al.11 mengemukakan adanya beberapa alasan para pihak memilih arbitrase sebagai forum penyelesaian sengketa, yaitu: "privacy and choice in the tribunal, flexibility, neutrality and equality, and enforceability of award." Jelas di sini, arbitrase dipilih oleh para pihak disebabkan adanya beberapa keuntungan tertentu yang tidak mungkin diperolehnya jika harus membawa sengketa mereka ke pengadilan. Arbitrase juga sering disebut sebagai ajudikasi privat. Hal ini dikarenakan dalam arbitrase, para pihak dapat memilih hakim yang mereka inginkan, yang berbeda dengan sistem pengadilan yang telah menetapkan hakim yang akan berperan, dengan demikian dapat menjamin baik kenetralan maupun keahlian, yang mereka anggap perlu dalam sengketa mereka. ${ }^{12}$

Kepailitan adalah suatu konsep hukum yang dipergunakan untuk menyelesaikan sengketa tentang utang-piutang yang timbul di antara kreditor dan debitor. Istilah kepailitan berasal dari kata "pailit" yang merupakan suatu keadaan di mana debitor tidak mampu untuk melakukan pembayaran-pembayaran terhadap utang-utang dari para kreditornya. ${ }^{13}$

Kepailitan dan utang seperti dua sisi dari satu mata uang yang tidak terpisahkan. ${ }^{14}$ Tanpa ada utang maka tidak mungkin perkara kepailitan akan dapat diperiksa. Esensi kepailitan tersebut ada pada utang karena kepailitan merupakan pranata hukum untuk melakukan likuidasi aset debitor untuk membayar utangutangnya terhadap para kreditornya. Utang merupakan raison d'etre dari suatu kepailitan. ${ }^{15}$ Hal tersebut juga ditegaskan dalam Pasal 2 ayat (1) UU Kepailitan yang mengatur syarat-

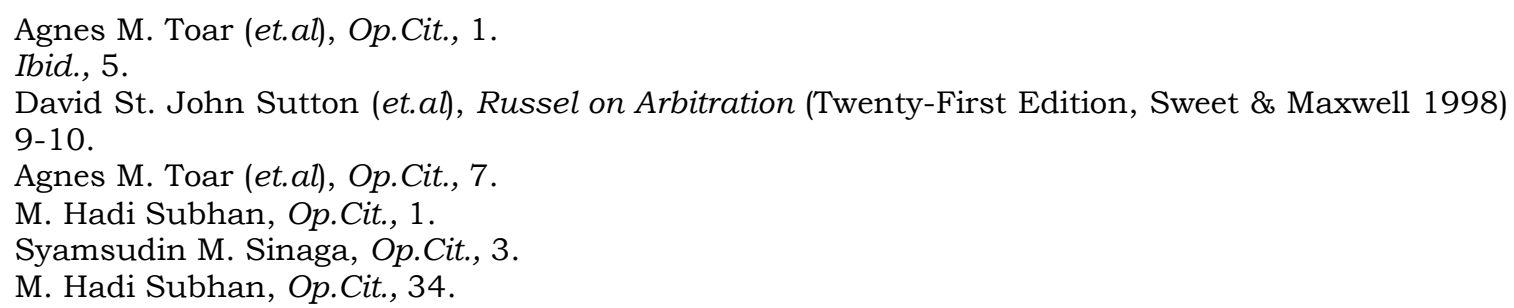


syarat kepailitan, yaitu: "Debitor yang mempunyai dua atau lebih Kreditor dan tidak membayar lunas sedikitnya satu utang yang telah jatuh waktu dan dapat ditagih, dinyatakan pailit dengan putusan Pengadilan baik atas permohonannya sendiri maupun satu atau lebih kreditornya". Ketentuan tersebut menegaskan bahwa adanya utang menjadi salah satu unsur utama untuk memailitkan debitor. Utang yang dijadikan dasar mengajukan kepailitan harus memenuhi unsur sebagai berikut: 1. Utang tersebut telah jatuh tempo; 2. Utang tersebut dapat ditagih; dan 3. Utang tersebut tidak dibayar lunas. ${ }^{16}$

Perkara kepailitan timbul karena adanya sengketa utang-piutang, yang dapat bersumber dari perjanjian atau UU. Pasal 1 ayat (6) UU Kepailitan memberikan batasan yuridis utang sebagai "kewajiban yang dinyatakan atau dapat dinyatakan dalam jumlah uang Indonesia maupun mata uang asing, baik secara langsung maupun yang akan timbul di kemudian hari atau kontinjen, yang timbul karena perjanjian atau Undang-Undang dan wajib dipenuhi oleh Debitor dan bila tidak dipenuhi memberi hak kepada Kreditor untuk mendapat pemenuhan dari harta kekayaan". Pengertian utang yang luas tersebut tidak dengan sendirinya dapat menjadi alasan bagi kreditor untuk mengajukan pailit debitor yang mengalami kegagalan untuk membayar utangnya, karena harus dikaitkan dengan persyaratan yang disebutkan di dalam Pasal 2 ayat (1) UU Kepailitan di atas.
Pengadilan niaga merupakan pengadilan khusus dalam lingkungan peradilan umum yang memiliki kompetensi absolut untuk memeriksa dan memutus perkara pailit dan perkara penundaan kewajiban pembayaran utang (PKPU), di samping perkara lain di bidang perniagaan. ${ }^{17}$ Tugas dan wewenang tersebut harus dilaksanakan berdasarkan asas peradilan pada umumnya, yaitu sederhana, cepat dan biaya ringan, di samping asas khusus pengadilan niaga, yaitu adil, cepat, terbuka, dan efektif. ${ }^{18}$ Dimasukkannya keadilan sebagai asas khusus bermakna bahwa penggunaan kewenangan pengadilan niaga harus dapat memberikan perlindungan hukum yang seimbang dan tidak memihak kepada pemangku kepentingan (stakeholders), baik bagi debitor, kreditor, maupun masyarakat. Penegakan hukum kepailitan jangan sampai mengabaikan keadilan. Keadilan dan kepastian hukum adalah tujuan utama dari hukum kepailitan Indonesia. ${ }^{19}$

\section{Konsep Hukum Penyelesaian Sengketa Bisnis}

Istilah hukum penyelesaian sengketa terdiri dari dua kata, yaitu "hukum" dan "penyelesaian sengketa bisnis." Hukum dalam tulisan ini dapat dimaknai sebagai kaidahkaidah atau norma-norma yang tertulis dan tidak tertulis yang mengatur masyarakat.

Istilah penyelesaian sengketa bisnis diartikan sebagai upaya yang dilakukan untuk menyelesaikan atau

\footnotetext{
Ibid., 91.

Syamsudin M. Sinaga, Op.Cit., 333.

Konsiderans menimbang huruf e dan f UU No. 4 Tahun 1998 dan penjelasan umum alinea enam UU No. 37 Tahun 2004 tentang Kepailitan.

19 Syamsudin M. Sinaga, Op.Cit., 327.
} 
mengakhiri suatu perselisihan atau konflik yang timbul dalam kegiatan bisnis. Sengketa atau konflik pada dasarnya dapat berdimensi hukum dan non-hukum. Sengketa yang berdimensi hukum lazimnya timbul karena terdapat pelanggaran hukum atau terjadi kerugian yang dapat dituntut pemenuhannya melalui lembaga pengadilan. Sengketa yang berdimensi non-hukum lebih diwarnai oleh adanya perbedaan pendapat atau pandangan yang tidak dapat dituntut atau diselesaikan melalui pengadilan karena tidak ada hukum atau UU yang dilanggar.

Konsep hukum penyelesaian sengketa bisnis muncul sebagai konsep untuk menjelaskan aturanaturan yang berlaku atau yang menjadi rujukan dalam menyelesaikan perselisihan hukum yang terjadi di dalam kegiatan bisnis yang dilakukan oleh masyarakat. Aturanaturan penyelesaian sengketa pada umumnya disebut juga procedural law, yang artinya hukum tentang prosedur atau tata cara untuk menyelesaikan suatu sengketa.

Sengketa yang timbul dalam kegiatan bisnis atau perdagangan dapat terjadi setelah para pihak menyepakati perjanjian atau kontrak yang mereka tandatangani. Ketika sengketa tersebut timbul, maka pilihan untuk menyelesaikan dapat dilakukan secara litigasi dan non litigasi.

\section{a. Penyelesaian Sengketa Bisnis Secara Litigasi}

Dalam konteks sengketa bisnis, penyelesaian sengketa secara litigasi atau melalui pengadilan terjadi setelah salah satu pihak gagal memenuhi perjanjian atau kontrak yang disepakati atau melakukan perbuatan yang merugikan pihak lain. Kontrak yang telah disepakati dan ditandatangani oleh para pihak merupakan UU atau hukum yang berlaku dan mengikat bagi para pihak. Hal ini merupakan konsekuensi logis dari dianutnya asas Pacta Sunt Servanda, yang berarti perjanjian mengikat selayaknya UU bagi para pihak. Demikian pula halnya perbuatan yang merugikan pihak lain melahirkan hak pihak yang dirugikan tersebut untuk menuntut ganti kerugian melalui lembaga pengadilan.

Dalam praktik, untuk menghindari terjadinya sengketa bisnis setelah suatu kontrak disepakati dan ditandatangani, biasanya para pihak melibatkan konsultan hukum atau penasihat hukum (legal adviser) dalam merancang atau pun menganalisis suatu draft kontrak sebelum kontrak tersebut ditandatangani. Jika upaya tersebut ditempuh, maka umumnya sangat kecil timbulnya sengketa bisnis. Namun yang sering menjadi persoalan adalah ketika para pihak pada awalnya hanya mengandalkan rasa saling percaya, selanjutnya ternyata terjadi permasalahan atau konflik, sehingga menimbulkan persoalan bagaimana cara menyelesaikan konflik yang dihadapi oleh para pelaku bisnis tersebut. Membawa persoalan atau konflik tersebut untuk diselesaikan dan diputuskan oleh pengadilan biasanya terjadi kalau para pihak gagal atau tidak bersedia untuk menempuh penyelesaian secara damai, bahkan di antara para pihak telah kehilangan kepercayaan di antara mereka.

b. Penyelesaian Sengketa Bisnis
Secara Non Litigasi

Istilah penyelesaian sengketa secara non litigasi digunakan sebagai 
lawan dari penyelesaian sengketa secara litigasi, yang berarti sengketa yang terjadi diselesaikan di luar pengadilan. Sengketa yang diselesaikan secara non litigasi pada umumnya terdiri dari sengketa-sengketa yang bersifat keperdataan.

Secara teoritik, ruang lingkup sengketa bisnis yang dapat diselesaikan secara non-litigasi pada dasarnya merupakan sengketa-sengketa timbul dari hubungan hukum yang sepenuhnya dikuasi oleh hukum para pihak. Artinya, sengketa hukum bisnis tersebut sebenarnya terjadi karena perjanjian atau kontrak di antara para pihak, yang jika timbul sengketa di antara mereka telah disepakati untuk diselesaikan di luar pengadilan. Para pihak sengaja menghindari penyelesaian sengketa di pengadilan, khususnya sengketa bisnis, dan memilih penyelesaian sengketa bisnisnya di luar pengadilan karena melihat adanya kelemahan pengadilan. Menurut Dwi Bintang Satrio dan Efa Laela Fakhriah, paling tidak ada beberapa alasan yang dapat dimaklumi, yaitu penyelesaian sengketa perdata melalui pengadilan dipandang tidak efektif dan efisien, hakim yang dinilai kurang menguasai subtansi permasalahan, dan penyelesaian sengketa melalui pengadilan seringkali membutuhkan waktu penyelesaian yang lama, yang mengindikasikan tidak adanya jamian penyelesaian sengketa dapat berjalan dengan cepat. ${ }^{20}$

Dasar hukum yang memungkinkan dapat tidaknya sengketa bisnis diselesaikan di luar pengadilan adalah UU No. 30 Tahun 1999 tentang Arbitrase dan Alternatif Penyelesaian
Sengketa (selanjutnya disebut UU Arbitrase). Pasal 2 UU tersebut menyatakan: "Undang-Undang ini mengatur penyelesaian sengketa atau beda pendapat antar para pihak dalam suatu hubungan hukum tertentu yang telah mengadakan perjanjian arbitrase yang secara tegas menyatakan bahwa semua sengketa atau beda pendapat yang timbul atau yang mungkin timbul dari hubungan hukum tersebut akan diselesaikan dengan cara arbitrase atau melalui alternatif penyelesaian sengketa". Untuk memahami maksud ketentuan Pasal 2 UU Arbitrase tersebut, perlu dikaitkan dengan pengertian "arbitrase" yang diatur di dalam Pasal 1 angka 1, dan pengertian "alternatif penyelesaian sengketa" dalam Pasal 1 angka 10 UU Arbitrase.

Pasal 1 angka 1 UU Arbitrase memberikan definisi "Arbitrase adalah cara penyelesaian suatu sengketa perdata di luar peradilan umum yang didasarkan pada perjanjian arbitrase yang dibuat secara tertulis oleh para pihak yang bersengketa." Pasal 1 angka 10 UU Arbitrase: "Alternatif Penyelesaian Sengketa adalah lembaga penyelesaian sengketa atau beda pendapat melalui prosedur yang disepakati para pihak, yakni penyelesaian di luar pengadilan dengan cara konsultasi, negosiasi, mediasi, konsiliasi atau penilaian ahli." Dari uraian di atas dapat diketahui bahwa ruang lingkup sengketa bisnis yang dapat diselesaikan di luar pengadilan adalah sengketa perdata yang timbul dari suatu perjanjian yang para pihak menyepakati terlebih dahulu bahwa

20 Dwi Bintang Satrio dan Efa Laela Fakhriah, 'Upaya Hukum Peninjauan Kembali Terhadap Putusan Pengadilan yang Membatalkan Putusan Arbitrase Nasional Dihubungkan dengan Prinsip Access to Justice' (2018) 2 Jurnal Bina Mulia Hukum 193, 193. 
sengketa tersebut harus diselesaikan dengan cara arbitrase atau cara alternatif penyelesaian sengketa.

Telah dikemukakan di atas bahwa penyelesaian sengketa bisnis di luar pengadilan telah mendapat pengaturan di dalam UU Arbitrase. Di dalam UU Arbitrase disebutkan beberapa cara sebagai bentuk-bentuk penyelesaian sengketa. Pertama, penyelesaian secara arbitrase, yaitu penyelesaian sengketa berdasarkan adanya perjanjian arbitrase. Pasal 1 angka 3 UU Arbitrase mengartikan perjanjian arbitrase adalah suatu kesepakatan berupa klausula arbitrase yang tercantum dalam suatu perjanjian tertulis yang dibuat para pihak sebelum timbul sengketa, atau suatu perjanjian arbitrase tersendiri yang dibuat setelah timbul sengketa. Berdasarkan pengertian tersebut dapat diperoleh pemahaman bahwa penyelesaian sengketa dengan cara arbitrase dapat disepakati oleh para pihak sebelum terjadi sengketa bisnis di antara mereka, atau setelah terjadi sengketa terlebih dahulu, kemudian barulah para pihak menyepakati untuk menyelesaikannya dengan cara arbitrase. Penegasan tentang hal tersebut dapat dicermati di dalam Pasal 7 UU Arbitrase yang menyatakan: "Para pihak dapat menyetujui suatu sengketa yang terjadi atau yang akan terjadi antara mereka untuk diselesaikan melalui arbitrase". Dalam literatur hukum bisnis dikemukakan bahwa penyelesaian sengketa melalui lembaga arbitrase dapat disepakati sebelum timbul sengketa atau Pactum de Compromittendo, dan setelah timbul sengketa atau Acta Kompromis.

Kedua, di samping cara arbitrase, dikenal pula lembaga penyelesaian sengketa yang disebut dengan alternatif penyelesaian sengketa. Lembaga penyelesaian sengketa ini memiliki beberapa cara, mulai dari konsultasi, negosiasi, mediasi, konsiliasi, atau penilaian ahli. Dikatakan sebagai lembaga penyelesaian sengketa atau beda pendapat karena melalui cara-cara tersebut, oleh para pihak, juga dapat dihasilkan suatu solusi untuk mengakhiri suatu sengketa atau konflik tanpa memerlukan keterlibatan lembaga pengadilan. Namun demikian, berdasarkan ketentuan Pasal 6 ayat (1) UU Arbitrase, penyelesaian sengketa melalui alternatif penyelesaian sengketa tersebut harus didasarkan adanya itikad baik dari kedua belah pihak yang bersengketa.

\section{Dapat-tidaknya Klausula Arbitrase Menghentikan Proses Pengajuan Permohonan Kepailitan terhadap Debitor}

Dalam bagian ini akan diuraikan tentang dapat tidaknya proses pengajuan permohonan kepailitan terhadap debitor dihentikan karena adanya klausula arbitrase dengan mengkaji dari sudut peraturan perundang-undangan yang berlaku, khususnya yang diatur di dalam UU Arbitrase dan UU Kepailitan

Dalam Pasal 58 UU No. 48 Tahun 2009 tentang Kekuasaan Kehakiman (selanjutnya disebut UU Kekuasaan Kehakiman) diatur bahwa upaya penyelesaian sengketa perdata dapat dilakukan di luar pengadilan negara melalui melalui arbitrase dan alternatif penyelesaian sengketa. Di samping itu, Pasal 59 UU Kekuasaan Kehakiman tersebut menegaskan lebih jauh bahwa: (1) Arbitrase merupakan cara penyelesaian suatu sengketa perdata di luar pengadilan 
yang didasarkan pada perjanjian arbitrase yang dibuat secara tertulis oleh para pihak yang bersengketa. (2) Putusan arbitrase bersifat final dan mempunyai kekuatan hukum tetap dan mengikat para pihak. (3) Dalam hal para pihak tidak melaksanakan putusan arbitrase secara sukarela, putusan dilaksanakan berdasarkan perintah ketua pengadilan negeri atas permohonan salah satu pihak yang bersengketa.

Ketentuan UU Kekuasaan Kehakiman tersebut di atas mengandung suatu prinsip bahwa sengketa perdata tidak selalu harus diselesaikan melalui proses gugatan di pengadilan (prinsip litigasi). Para pihak yang bersengketa dimungkinkan untuk mencari dan menyepakati forum lain di luar forum pengadilan untuk memeriksa dan memutus sengketa tersebut (prinsip non litigasi). Jika ditelisik lebih jauh, prinsip hukum penyelesaian sengketa perdata di luar pengadilan bertujuan agar para pihak yang bersengketa dapat mengakhiri sengketanya secara win-win solution. Dengan penyelesaian secara win-win solution, maka tidak pihak yang merasa tidak puas dengan putusan yang diambil oleh karena putusan tersebut sebenarnya dibuat berdasarkan aturan hukum dan proses hukum yang disepakati kedua belah pihak. Akan berbeda halnya dengan penyelesaian di dalam pengadilan, yang para pihak akan mengakhiri sengketa di antara mereka secara win-lose solution, yang bermakna selalu ada pihak yang akan dikalahkan.
Prinsip hukum penyelesaian sengketa perdata secara non litigasi dapat dilaksanakan dengan memilih lembaga-lembaga penyelesaian sengketa, seperti lembaga arbitrase. Eksistensi lembaga penyelesaian sengketa tersebut telah memiliki landasan hukum yang kuat, yaitu di dalam UU Arbitrase, yang putusan arbitrase tersebut dapat dikategorikan menjadi dua, yakni putusan arbitrase domestik dan putusan arbitrase asing (internasional). ${ }^{21}$

Secara definisi, arbitrase diartikan sebagai cara penyelesaian suatu sengketa perdata di luar peradilan umum yang didasarkan pada perjanjian arbitrase yang dibuat secara tertulis oleh para pihak yang bersengketa. ${ }^{22}$ Dengan demikian, dasar dilakukannya penyelesaian sengketa perdata di luar pengadilan adalah kebebasan berkontrak di antara para pihak, yang bersepakat untuk memeriksa, menyelesaikan dan mengakhiri sengketa di antara mereka dengan membuat suatu perjanjian tertulis.

Sengketa perdata yang dapat diselesaikan melalui lembaga arbitrase juga telah dibatasi oleh UU, yaitu hanya sengketa di bidang perdagangan dan mengenai hak yang menurut hukum dan peraturan perundangundangan dikuasai sepenuhnya oleh pihak yang bersengketa. Adapun sengketa yang tidak dapat diselesaikan melalui arbitrase adalah sengketa yang menurut peraturan perundangundangan tidak dapat diadakan perdamaian. ${ }^{23}$

21 Sashia Diandra Anindita dan Prita Amalia, 'Klasifikasi Putusan Arbitrase Internasional Menurut Hukum Indonesia Ditinjau dari Hukum Internasional' (2017) 2 Jurnal Bina Mulia Hukum 43, 43.

22 Pasal 1 angka 1 UU No. 30 Tahun 1999 tentang Arbitrase dan Alternatif Penyelesaian Sengketa.

23 Pasal 5 UU No. 30 Tahun 1999 tentang Arbitrase dan Alternatif Penyelesaian Sengketa. 
Sayangnya, UU Arbitrase tidak mem-berikan batasan atau definisi apa yang dimaksud dengan sengketa di bidang perdagangan. Dalam penjelasan Pasal 5 UU Arbitrase hanya dinyatakan "cukup jelas". Tampaknya, pembentuk UU menyerahkan masalah tersebut kepada perkembangan ilmu pengetahuan hukum itu sendiri.

Pasal 3 UU Arbitrase menyatakan: "Pengadilan Negeri tidak berwenang untuk mengadili sengketa para pihak yang telah terikat dalam perjanjian arbitrase". Pasal 11 ayat (2) UU Arbitrase juga mempertegas: "Pengadilan Negeri wajib menolak dan tidak akan campur tangan di dalam suatu penyelesaian sengketa yang telah ditetapkan melalui arbitrase, kecuali hal-hal tertentu yang ditetapkan dalam undang-undang ini". Berkaitan dengan ketentuan tersebut, tidak ada satu pasal pun di dalam UU Arbitrase yang memberikan pengecualian kepada pengadilan negeri untuk memeriksa perkara sengketa perjanjian utang-piutang yang diselesaikan melalui peradilan kepailitan. Pengadilan niaga sebagai pengadilan khusus yang berada di dalam lingkungan peradilan umum seyogyanya juga tunduk kepada UU Arbitrase tersebut.

Berdasarkan uraian di atas dapat diketahui bahwa telah terjadi ketidaksinkronan di antara UU Arbitrase dengan UU Kepailitan terkait dengan kekuatan hukum klausula arbitrase sebagai dasar hukum dalam menyelesaikan sengketa utang-piutang di antara kreditor dan debitor. UU
Arbitrase jelas-jelas memberikan dasar hukum yang kuat bagi para pihak yang telah mengadakan perjanjian atau kesepakatan untuk memilih arbitrase sebagai forum penyelesaian sengketa sepanjang halhal yang menyangkut kepentingan keperdataan para pihak. Pasal 10 UU Arbitrase menegaskan bahwa perjanjian arbitrase tidak menjadi batal oleh keadaan antara lain bangkrutnya salah satu pihak atau insolvensi salah satu pihak. ${ }^{24} \mathrm{Hal}$ ini diperkuat lagi dengan adanya asas Pacta Sunt Servanda dan asas Freedom of Contract yang menjamin dan menjadi dasar mengikatnya klausula arbitrase sebagai UU bagi para pihak. Pengadilan sekalipun tidak boleh menolak adanya klausula arbitrase tersebut terkecuali jika UU Arbitrase memberikan landasan yuridisnya. Di sisi lainnya, UU Kepailitan merupakan UU yang dibuat untuk mengatur bagaimana cara mempailitkan seorang debitor atas dasar putusan pengadilan (niaga) agar supaya harta si debitor atau budel pailit diletakkan di bawah sita umum. Namun UU Kepalitan tidak dapat membatalkan klausula arbitrase yang merupakan UU bagi para pihak. Sehingga, menurut penulis, seyogyanya klausula arbitrase dapat digunakan oleh para pihak untuk menghentikan proses pemailitan debitor, dan hakim pengadilan niaga seyogyanya memakai klausula arbitrase tersebut untuk menyatakan permohonan pemailitan si debitor dinyatakan tidak dapat diterima.

24 Pasal 10 UU No. 30 Tahun 1999 tentang Arbitrase dan Alternatif Penyelesaian Sengketa: "Suatu perjanjian arbitrase tidak menjadi batal disebabkan oleh keadaan tersebut di bawah ini: 1. meninggalnya salah satu pihak; 2 . bangkrutnya salah satu pihak; 3 . novasi; 4. insolvensi salah satu pihak; 5. pewarisan; 6. berlakunya syarat-syarat hapusnya perikatan pokok; 7 . bilamana pelaksanaan perjanjian tersebut dialihtugaskan pada pihak ketiga dengan persetujuan pihak yang melakukan perjanjian arbitrase tersebut; atau 8. berakhirnya atau batalnya perjanjian pokok". 


\section{Kewenangan Pengadilan Niaga untuk Mengenyampingkan Klausula Arbitrase dalam Kaitan dengan Prinsip Commercial Exit from Financial Distress}

Dalam bagian ini akan diuraikan tentang pengaturan yang terkait dengan kewenangan pengadilan niaga sebagai pengadilan khusus yang berada di dalam lingkungan peradilan umum dalam mengesampingkan klausula arbitrase yang dikaitkan dengan prinsip Commercial Exit from Financial Distress sebagai salah satu prinsip hukum kepailitan, sejauh mana hal tersebut dikatakan bertentangan.

Perkara kepailitan merupakan salah satu perkara yang proses peradilannya dilakukan melalui pengadilan khusus, yaitu pengadilan niaga. Saat ini, pengadilan niaga yang ada di Indonesia hanya ada di 5 (lima) kota, yaitu Pengadilan Niaga Jakarta Pusat, Ujung Pandang, Medan, Surabaya dan Semarang. Pengadilan niaga adalah pengadilan khusus yang diatur berdasarkan UU dan memiliki kewenangan absolut untuk memeriksa dan memutus permohonan pernyataan pailit dan penundaan kewajiban pembayaran utang sebagaimana ditegaskan di dalam ketentuan Pasal 300 ayat (1) UU Kepailitan.

Menurut ketentuan Pasal 2 ayat (4) UU Kepailitan, pengadilan niaga dengan kompetensi absolutnya itu pada dasarnya harus mengabulkan permohonan pernyataan pailit apabila terdapat fakta atau keadaan yang terbukti secara sederhana bahwa persyaratan untuk dinyatakan pailit sebagaimana dimaksud dalam Pasal 2 ayat (1) UU Kepailitan telah terpenuhi. Itu artinya, ketika dapat dibuktikan secara sederhana bahwa permohonan pailit tersebut telah memenuhi syarat substantif berupa adanya utang, utang tersebut telah jatuh tempo dan dapat ditagih, terdapat dua atau lebih kreditor, dan debitor tidak membayar lunas sedikitnya satu utang, maka pengadilan niaga harus memutuskan menerima dan menyatakan pailit debitor tersebut.

Akan tetapi, menurut penulis, kompetensi absolut pengadilan niaga untuk memeriksa dan memutus permohonan pernyataan pailit dan penundaan kewajiban pembayaran utang tidak boleh dijalankan secara sewenang-wenang tanpa mengkaitkannya dengan prinsip-prinsip hukum penyelesaian sengketa melalui arbitrase yang diuraikan sebelumnya dan prinsip hukum kepailitan lainnya. Salah satu prinsip hukum kepailitan lain yang terkait dengan kompetensi absolut pengadilan (niaga) adalah prinsip Commercial Exit from Financial Distress, yang bermakna bahwa kepailitan harus menjadi solusi terhadap masalah penyelesaian utang debitor yang sedang mengalami kebangkrutan, dan bukan sebaliknya dalam arti kepailitan dijadikan pranata hukum untuk membangkrutkan suatu usaha. ${ }^{25}$ Berdasarkan prinsip tersebut, hakim pengadilan (niaga) seharusnya dapat menyatakan tidak menerima permohonan pailit yang terindikasi adanya "hidden agenda" untuk membangkrutkan atau mengakhiri bisnis dari si debitor. Prinsip Commercial Exit from Financial Distress berhubungan erat secara khususnya dengan kepailitan perseroan terbatas yang benar-benar 
dalam kondisi yang tidak mungkin lagi untuk diselamatkan secara finansial.

Penyelamatan secara finansial sebuah perseroan terbatas biasanya dilakukan dengan melakukan restrukturisasi utang-utangnya. Tujuannya untuk mempertahankan perseroan sebagai debitor untuk tetap menjalankan usahanya sebagai suatu going concern, yaitu memberi kesempatan kepada debitor yang masih mempunyai prospek baik untuk diberikan waktu agar dapat melunasi utangutangnya, yang dilakukan dengan memperbaharui atau tidak memperbaharui syarat-syarat perjanjian utangnya. ${ }^{26}$ Dengan demikian, kreditor-kreditor lainnya yang memiliki tagihan relatif kecil dan tidak berkehendak memailitkan debitor memiliki harapan untuk mendapatkan pelunasan tagihannya dari debitor yang beritikad baik tersebut.

Dalam hukum kepailitan moderen, kepailitan seyogyanya dipakai sebagai instrumen hukum terakhir yang dipergunakan oleh para pihak untuk menyelesaikan persoalan utangpiutang yang dihadapi suatu perseroan. Instrumen hukum kepailitan memiliki kekhasan yang tidak dimaksudkan untuk "membunuh" bisnis debitor, melainkan justru untuk mengeluarkan si debitor dari tekanan bisnis. Pengadilan kepailitan, seperti halnya pengadilan pada umumnya menjadi tumpuan keadilan bagi seluruh masyarakat pencari keadilan. ${ }^{27}$ Oleh karena itu, ketika dalam memeriksa dan memutus permohonan kepailitan, hakim menemukan terdapat bukti di dalam perjanjian bisnis di antara kreditor dan debitor adanya klausula arbitrase, hal tersebut dapat ditafsirkan sebagai solusi yang wajib ditempuh untuk menyelamatkan bisnis si debitor yang beritikad baik. Hakim pengadilan (niaga) seyogyanya memberikan kesempatan kepada lembaga arbitrase untuk terlebih dahulu memastikan apakah debitor memiliki itikad baik atau tidak untuk membayar utangutangnya kepada kreditor. Dengan demikian, adanya ketentuan dalam Pasal 303 UU Kepailitan yang membolehkan pengadilan niaga untuk mengenyampingkan klausula arbitrase dalam memeriksa dan menyelesaikan permohonan pernyataan pailit para pihak yang terikat perjanjian arbitrase pada dasarnya bertentangan dengan prinsip hukum kepailitan sebagai Commercial Exit from Financial Distress. Pengecualian terhadap prinsip tersebut hanya dimungkinkan jika terdapat indikasi bahwa si debitor tidak memiliki itikad baik, misalnya debitor tidak diketahui keberadaanya atau melakukan pengalihan asetnya kepada pihak lain dalam jumlah besar pada saat permohonan pernyataan pailit terhadapnya diajukan.

\section{Pertimbangan Hakim Pengadilan Niaga terhadap Klausula Arbitrase dalam Perjanjian Utang-Piutang Kreditor dan Debitor yang Diajukan Pailit oleh Kreditornya}

Pada bagian ini akan diuraikan bagaimana hakim dalam mempertimkan klausula arbitrase yang terdapat

\footnotetext{
$26 \quad$ Ibid., 61.

27 Catur Irianto, 'Penerapan Asas Kelangsungan Usaha dalam Penyelesaian Perkara Kepailitan dan Penundaan Kewajiban Pembayaran Utang (PKPU) (The Application of the Principle of Business Continuity in Bankruptcy Settlement and Debt Payment Suspention) (2015) 4 Jurnal Hukum dan Peradilan 399, 408.
} 
di dalam perjanjian utang-piutang di antara kreditor dan debitor yang sedang diajukan pailit untuk melihat dasar pertimbangan hukum yang dipergunakan hakim pengadilan niaga yang bersangkutan.

Isu klausula arbitrase yang timbul dalam perkara kepailitan tersebut terkait dengan masalah kompetensi absolut pengadilan niaga di satu sisi, dan prinsip hukum penyelesaian sengketa melalui arbitrase yang telah menjadi prinsip universal yang dianut di dalam kontrak-kontrak bisnis atau perdagangan, baik secara nasional maupun internasional. Perkara kepailitan merupakan kompetensi absolut pengadilan niaga berdasarkan ketentuan Pasal 6 ayat (1) jo Pasal 300 ayat (1) UU Kepailitan, yang menyatakan bahwa permohonan pernyataan pailit diajukan kepada ketua pengadilan niaga yang berwenang memeriksa permohonan pernyataan pailit dan penundaan kewajiban pembayaran utang. Pada sisi ini, pengadilan niaga sebagai pengadilan khusus di lingkungan peradilan umum diberikan wewenang untuk memeriksa dan memutuskan perkara permohonan pernyataan pailit berdasarkan oleh UU Kepailitan. Namun, pengadilan niaga, yang memiliki kekhususan sebagai lembaga peradilan bagi sengketa-sengketa kepailitan dan sengketa-sengketa tertentu di bidang perniagaan, seharusnya dipergunakan sebagai upaya terakhir atau the last resort bagi para pihak, yaitu apabila penyelesaian di luar pengadilan, dalam hal ini melalui lembaga arbitrase yang disepakati para pihak telah ditempuh dan tidak ada itikad baik debitor untuk melaksanakan putusan lembaga arbitrase.

Perjanjian utang-piutang yang diadakan di antara kreditor dan debitor yang mengandung klausula arbitrase cukup sering dijumpai, antara lain dalam perjanjianperjanjian bisnis moderen. Klausula arbitrase diadakan sebagai dasar hukum bagi para pihak dalam suatu kontrak untuk menyelesaikan sengketa yang timbul di antara mereka. Sengketa wanprestasi adalah sengketa yang dominan timbul di antara para pihak karena berkaitan dengan tidak dipenuhinya apa yang menjadi prestasi atau kontra prestasi yang seharusnya.

Dalam konteks perkara kepailitan yang di dalam perjanjian utangpiutangnya memuat klausula arbitrase, sebuah penelitian yang dilakukan Rahayu Hartini28 menemukan fakta bahwa dari 491 putusan pailit yang diputus oleh pengadilan niaga maupun Mahkamah Agung (MA) sejak tahun 1998 s/d 2004, terdapat 5 (lima) perkara yang di dalamnya perjanjian utang-piutangnya memuat klausul arbitrase, yang pada pokoknya menggambarkan adanya dualisme aturan yang memberikan wewenang kepada pengadilan niaga dan lembaga arbitrase untuk menyelesaikan sengketa perjanjian utang-piutang.

Seiring berjalannya waktu, UU Kepailitan yang lama (UU No. 4 Tahun 1998) kemudian dicabut dan digantikan dengan UU No. 37 Tahun 2004, memunculkan suatu ketentuan yang memberikan kewenangan yang ekplisit kepada pengadilan niaga

28 Rahayu Hartini, 'UUK dan PKPU No. 37 Th 2004 Mengesampingkan Berlakunya Asas Pacta Sunt Servanda dalam Penyelesaian Sengketa Kepailitan’ (2015) 4 Yustisia 292, 295. 
untuk memeriksa dan menyelesaikan permohonan pernyataan pailit dari para pihak yang terikat perjanjian yang memuat arbitrase (Pasal 303 UU Kepailitan), tetapi sayangnya tidak diikuti dengan mengamandemen UU Arbitrase yang jelas-jelas menganut suatu prinsip bahwa pengadilan negeri tidak berwenang mengadili sengketa para pihak yang telah terikat perjanjian arbitrase. ${ }^{29}$ Ketidaksinkronan aturan antara kewenangan lembaga arbitrase dan pengadilan kepailitan tersebut masih berlangsung hingga saat ini dan dapat menimbulkan ketidakpastian hukum bagi kreditor dan debitor. Kreditor berkepentingan untuk mendapatkan kepastian menuntut pemenuhan pelunasan utangnya melalui lembaga kepailitan, sementara debitor berkepentingan untuk memperoleh kepastian penyelesaian secara arbitrase berlandaskan perjanjian arbitrase yang telah disepakati sebagai UU bagi para pihak.

Berikut ini akan diberikan suatu contoh putusan perkara kepailitan yang diputuskan oleh MA terkait dengan status klausula arbitrase dalam perjanjian bisnis antara kreditor dan debitor, namun ketika kreditor mengajukan permohonan pailit terhadap debitornya, MA menguatkan putusan pengadilan niaga yang menyatakan tidak berwenang memeriksa dan mengadili permohonan pailit terhadap debitor dikarenakan telah terdapat klausula arbitrase di antara kreditor dan debitornya. Hal ini dapat diketahui dari putusan MA No. 254 K/Pdt.SusPailit/2014. Sebelumnya perkara ini diawali dengan adanya permohonan pailit yang diajukan oleh PT Semangat Baru Putra selaku pemohon pailit terhadap PT Indo Graha Lestari selaku termohon pailit melalui Pengadilan Niaga Jakarta Pusat. Pengadilan Niaga Jakarta Pusat dalam putusan No. 02/Pdt.Sus-Pailit/2014/PN.Niaga.Jkt. Pst memberikan putusan terhadap permohonan pailit yang diajukan, yaitu: “(1) mengabulkan eksepsi dari termohon pailit; (2) menyatakan pengadilan niaga pada Pengadilan Negeri Jakarta Pusat tidak berwenang memeriksa dan mengadili perkara ini; (3) menghukum Pemohon Pailit untuk membayar biaya perkara sebesar Rp. $516.000,00$ (lima ratus enam belas ribu rupiah)". Salah satu eksepsi termohon pailit yang dipertimbangkan oleh hakim pengadilan niaga adalah adanya klausula arbitrase yang dituangkan secara tertulis ke dalam perjanjian kerja sama dengan termohon pailit (kontrak kerja konstruksi) yang menjadi dasar permohonan pailit tersebut.

MA dalam pertimbangan putusan kasasi yang diajukan oleh pemohon pailit/pemohon kasasi di atas memperkuat putusan Pengadilan Niaga Jakarta Pusat tersebut dengan pertimbangan bahwa Judex Factie, dalam hal ini putusan Pengadilan Niaga pada Pengadilan Negeri Jakarta Pusat ternyata tidak salah dalam menerapkan hukum dan telah memberikan pertimbangan yang cukup, karena dalam surat perjanjian kerja (P1) yang menjadi dasar hubungan hukum antara penggugat dengan tergugat terdapat klausula bahwa apabila terjadi perselisihan antara para pihak yang mengikatkan diri, maka mereka sepakat untuk

29 Pasal 3 UU No. 30 Tahun 1999 tentang Arbitrase dan Alternatif Penyelesaian Sengketa. 
menyelesaikan perselisihan mereka melalui Badan Arbitrase Nasional Indonesia. Pertimbangan MA juga menyatakan bahwa ternyata Putusan Pengadilan Niaga pada Pengadilan Negeri Jakarta Pusat dalam putusan No. 02/Pdt.Sus-Pailit/2014/PN.Niaga. Jkt.Pst. tanggal 27 Februari 2014 dalam perkara ini tidak bertentangan dengan hukum dan/atau UU, sehingga permohonan kasasi yang diajukan oleh pemohon kasasi PT Semangat Baru tersebut harus ditolak.

Menurut penulis, pertimbangan hakim dalam perkara permohonan pailit di atas, baik di dalam putusan pengadilan niaga maupun MA tersebut hendak mengukuhkan dan menegaskan kembali prinsip dasar penyelesaian sengketa di luar pengadilan, yaitu melalui lembaga arbitrase harus diprioritaskan penyelesaiannya karena hal tersebut telah menjadi prinsip hukum universal. Instrumen hukum kepailitan yang cenderung mempermudah kreditor untuk memailitkan debitor harus dipergunakan secara cermat dan bijaksana karena menyangkut kepentingan banyak pihak dan harus menjamin kepastian hukum dan keadilan bagi semua pihak secara berimbang. Dalam dunia bisnis, lembaga arbitrase memiliki peran penting dalam menyelesaikan konflik-konflik yang timbul dari perjanjian bisnis dengan mengutamakan pendekatan win-win solution dan kebebasan para pihak untuk memilih hukum dan arbiter (wasit) yang akan memutuskan sengketa para pihak. Hal ini tentu berbeda dengan instrumen hukum kepailitan yang tidak menggunakan pendekatan seperti halnya lembaga arbitrase. Penyelesaian sengketa utang-piutang melalui lembaga kepailitan cenderung memaksa pihak debitor di posisi yang lemah, dan kreditor di posisi yang kuat. Seharusnya, dalam hal debitor dapat menunjukkan itikad baiknya untuk membayar utangnya melalui lembaga arbitrase, hal ini tentunya akan memberikan peluang kepada kreditor-kreditor lainnya untuk memperoleh kepastian pembayaran akan utang-utangnya. Atas dasar itulah penulis berpendapat bahwa Pasal 303 UU Kepailitan seharusnya dihilangkan atau setidaknya diterapkan dengan persyaratan yang sangat ketat. Hal lainnya, tampaknya juga perlu dipikirkan oleh pembentuk UU adanya upaya untuk merevisi UU Arbitrase sepanjang ketentuan yang terkait dengan lembaga kepailitan, khususnya prinsip-prinsip yang dapat membatalkan perjanjian arbitrase.

\section{PENUTUP}

Sebagai akhir dari tulisan ini dapat ditarik beberapa simpulan sebagai berikut:

1. Klausula arbitrase yang tertuang di dalam perjanjian bisnis yang mengikat kreditor dan debitor pada prinsipnya dapat dijadikan dasar untuk menghentikan proses pengajuan permohonan kepailitan terhadap debitor atas dasar prinsip dalam UU Kekuasaan Kehakiman, UU Arbitrase, asas Pacta Sunt Servanda dan asas kebebasan berkontrak.

2. Kewenangan pengadilan niaga untuk mengenyampingkan klausula arbitrase yang tersirat di dalam Pasal 303 UU Kepailitan jika dikaitkan dengan prinsip Commercial Exit from Finansial Distress dalam hukum kepailitan justru berpotensi untuk melahirkan kesewenang-wenangan 
kreditor terhadap debitor yang beritikad baik untuk membayar utang-utangnya, termasuk dapat merugikan kreditor lainnya yang memiliki tagihan relatif kecil.

3. Pertimbangan hakim pengadilan niaga terhadap klausula arbitrase dalam perjanjian utang-piutang kreditor dan debitor yang diajukan pailit oleh kreditornya dalam putusan Nomor 02/Pdt. SusPailit/2014/PN.Niaga.Jkt.Pst. dan putusan No. 254 K/Pdt.SusPailit/2014 menunjukkan masih adanya konsistensi putusan tersebut terhadap asas-asas hukum yang berlaku universal tentang penyelesaian sengketa utang-piutang melalui arbitrase, yang tidak boleh disimpangi melalui lembaga hukum kepailitan tanpa dasar hukum yang kuat, yang memberikan kepastian dan keadilan bagi para pihak.

\section{DAFTAR BACAAN}

\section{Buku}

Manik, E., Cara Mudah Memahami Proses Kepailitan dan Penundaan Kewajiban Pembayaran Utang (Dilengkapi Dengan Studi Kasus Kepailitan) (Mandar Maju 2012).

Marzuki, Peter M., Penelitian Hukum (Ed. Pertama, Cet. Ketujuh, Kencana Prenada Media Group 2011).

Sembiring, S., Hukum Dagang (Ed. Revisi, Cet. Ketiga PT Citra Aditya Bakti 2008).

Sinaga, Syamsudin M., Hukum Kepailitan Indonesia (Tatanusa 2012).

Sjahdeini, Sutan R., Kebebasan Berkontrak dan Perlindungan yang
Seimbang Bagi Para Pihak Dalam Perjanjian Kredit Bank di Indonesia (PT Pustaka Utama Grafiti 2009).

Subhan, M. H., Hukum Kepailitan. Prinsip, Norma, dan Praktik di Peradilan (Kencana Prenada Media Group 2008).

Sutton, David St. J., (et.al)., Russel on Arbitration (Twenty-First Edition Sweet \& Maxwell 1998).

Toar, Agnes M., (et.al), Arbitrase di Indonesia. Seri Dasar-dasar Hukum Ekonomi 2 (Ghalia Indonesia 1995).

\section{Artikel Jurnal}

Anindita, Sashia D. dan Amalia, P., 'Klasifikasi Putusan Arbitrase Internasional Menurut Hukum Indonesia Ditinjau dari Hukum Internasional' (2017) 2 Jurnal Bina Mulia Hukum.

Hartini, R., 'UUK dan PKPU No. 37 Th $2004 \quad$ Mengesampingkan Berlakunya Asas Pacta Sunt Servanda dalam Penyelesaian Sengketa Kepailitan' (2015) 4 Yustisia.

Irianto, C., 'Penerapan Asas Kelangsungan Usaha dalam Penyelesaian Perkara Kepailitan dan Penundaan Kewajiban Pembayaran Utang (PKPU) (The Application of the Principle of Business Continuity in Bankruptcy Settlement and Debt Payment Suspention) (2015) 4 Jurnal Hukum dan Peradilan.

Satrio, Dwi Bintang S. dan Fakhriah, Efa L., Upaya Hukum Peninjauan Kembali Terhadap Putusan Pengadilan yang Membatalkan Putusan Arbitrase Nasional Dihubungkan dengan Prinsip Access to Justice (2018) 2 Jurnal 
Bina Mulia Hukum.

\section{Peraturan Perundang-Undangan}

Undang-Undang Nomor 30 Tahun 1999 tentang Arbitrase dan Alternatif Penyelesaian Sengketa.

Undang-Undang Nomor 37 Tahun 2004 tentang Kepailitan dan Penundaan Kewajiban Pembayaran Utang.

Undang-Undang Nomor 48 Tahun 2009 tentang Kekuasaan Kehakiman. 